\title{
KIMUN PLATFORM: WEB TOOL AS A PEDAGOGICAL RESOURCE FOR TEACHING AND LEARNING MAPUZUGUN
}

\author{
Marcos Levano $^{1}$, Mariajose Marro ${ }^{2}$ and Pablo Hernandez ${ }^{3}$ \\ ${ }^{I}$ Department of Computer Engineering \\ ${ }^{2}$ Department of Arts and Design \\ Catholic University of Teтисо \\ Av. Manuel Montt 56, Casilla 15-D, Temuco, Chile \\ ${ }^{3}$ Software Development Consultant, Chile
}

\begin{abstract}
In this article we present a knowledge management platform called Kim un (which means knowledge in Mapuzugun) as a technological web resource for teaching and learning Mapuzugun language. We discuss how we can generate a richness in multicultural education and diminish the otherness between different cultural groups in a society of XXI century towards a change of knowing and understanding, towards a cultural development for an e-society world. Today Mapuche language is going through difficult times, it's struggling for not ceasing to exist. As we know, the language is one of the patrimonies that defines a people identity, if the language dies, then the people and all their worldview disappears. Currently, Mapuche children are not learning Mapuzugun as their mother tongue for a variety of reasons. This situation further aggravates the problem of maintaining the Mapuche language and, with it, all the cultural richness of this ethnic group. Due to this complex scenario is that the government has implemented laws that allow a revitalization of this language, including teaching in those schools that have a high density of Mapuche students. The objective of this work is to bring together actors such as teachers, non-Mapuche and Mapuche students, researchers, Mapuche and native speakers to put the pedagogical resource for the teaching and learning of the Mapuche language as a multicultural tool as technological linguistic tools which are transversal to the disciplines of nowdays. The advances of this work are the base to create a platform focused on orienting a framework in the creation of learning virtual objects (OVAs in spanish).
\end{abstract}

\section{KEYWORDS}

Intercultural Education, Otherness, Linguistic Technologies, Mapuzugun Language, Learning Virtual Objects

\section{INTRODUCTION}

In Chile, the term Mapuche - or "earth people"- has been used by the majority indigenous peoples of Chile as self-denomination and generic term. This term has also been used as a synonym for Araucano, a lexeme by which the Spaniards designated the Mapuches. After Quechuas and Aymaras, they are the third largest indigenous society in the Americas, with a total of 928,060 inhabitants according to the Chilean census (CENSO, 2017); and the majority and best preserved indigenous culture of Chile (Lenz, 1895-1897).

The XVII national census of population and the VI of housing, both made in 2017 indicate that the population of Chile is $17,574,003$ inhabitants, of which 2,284,620 people (13\%) said they belong to one of the 9 indigenous peoples considered in the census instrument. The Chilean indigenous population according to their ethnicity is very heterogeneous. The Mapuche population stands out in the first place, corresponding to $79.8 \%$ of the total population. They are followed by the Aymara (7.2\%) and the Diaguita (4.1\%). The rest of the ethnic groups (Colla 0.9\%, Rapa Nui 0.4\%, Quechua 1.6\%, Y'amara 0.1\%, Colla 0.9\% others $1.3 \%$ ), together account for 4.5\% (CENSO, 2017), (Gundermann et al., 2009). 
Table 1. Distribution of mapuzugun competence according to age strata in southern Chile (regions of biobio, araucania, the rivers and the lakes), (CENSO, 2017)

\begin{tabular}{|c|c|c|c|c|}
\hline Age & Without competences & Basic & Intermediate & high \\
\hline $10-19$ & 27,$559 ; 85,7 \%$ & 1,$993 ; 6,2 \%$ & 1,$378 ; 4,3 \%$ & 1,$209 ; 3,8 \%$ \\
\hline $20-29$ & 30,$864 ; 80,6 \%$ & 2,$748 ; 7,2 \%$ & 3,$177 ; 8,3 \%$ & 1,$488 ; 3,9 \%$ \\
\hline $30-39$ & 31,$349 ; 69,1 \%$ & 1,$617 ; 3,6 \%$ & 5,$258 ; 11,6 \%$ & 7,$121 ; 15,7 \%$ \\
\hline $40-49$ & 2,$341 ; 61,2 \%$ & 1,$345 ; 3,1 \%$ & 5,$383 ; 12,5 \%$ & 9,$968 ; 23,2 \%$ \\
\hline $50-59$ & 16,$586 ; 47,5 \%$ & 1,$578 ; 4,5 \%$ & 4,$354 ; 12,5 \%$ & 12,$428 ; 35,6 \%$ \\
\hline $60-69$ & 12,$530 ; 44,5 \%$ & $183 ; 0,7 \%$ & 3,$003 ; 10,7 \%$ & 12,$422 ; 44,1 \%$ \\
\hline $70-79$ & 5,$205 ; 26,7 \%$ & $170 ; 0,9 \%$ & 1,$016 ; 5,2 \%$ & 13,$082 ; 67,2 \%$ \\
\hline $80-$ more & 1,$417 ; 25,4 \%$ & $264 ; 4,7 \%$ & $270 ; 4,8 \%$ & 3,$624 ; 65,0 \%$ \\
\hline Total & 151,$851 ; 61,5 \%$ & 9,$898 ; 4,0 \%$ & 23,$839 ; 9,7 \%$ & 61,$342 ; 24,8 \%$ \\
\hline
\end{tabular}

It is notorious and worrisome the setback of Mapuzugun, the Mapuche language, and its replacement by the Spanish. Phenomena of linguistic displacement are common to the continent Amerindian languages, even when they retain a several number of speakers. The disappearance of some indigenous languages and threats to the survival of others is one of the cultural concerns of indigenous politics over the last 20 years (Gundermann, 2005). Their action is not only a gesture of ethnic recognition; but also a way of facing the ongoing linguistic setback.

Table 1 shows weighted and projected figures for the entire Mapuche population of southern Chile, rural and urban, according to age groups in decades. A simple data inspection is sufficient to highlight the correlation between the increase or decrease of competence and the high age brackets or those of young and adults. Thus, for example, only a $14.3 \%$ of those between 10 and 19 years are proficient, focusing on basic and intermediate levels and with a good number of passive speakers. Something similar is repeated with the members of the group between 20 and 29 years, among which only 19.4\% shows competence. Among the elderly, the situation is reversed. A majority of those in the age group of 70-79 years shows competence (73.3\%), most in the high level (CENSO, 2017), (Lenz, 1895-1897).

Mapudungun, which means "the speaking of the earth", is one of the languages that, as mentioned above, is still used, but that is gradually disappearing, this defines the identity of Mapuche people including their philosophy, customs, rituals and their way of life. The Mapuzugun non-use by the Mapuches is due to the fact that most of people belonging to this ethnic group reside near the big cities, depending economically on them. Having to work in these cities and not in the countryside forces them to use the Spanish language instead of their native language, to be able to carry out marketing processes, attend school or carry out paperwork.

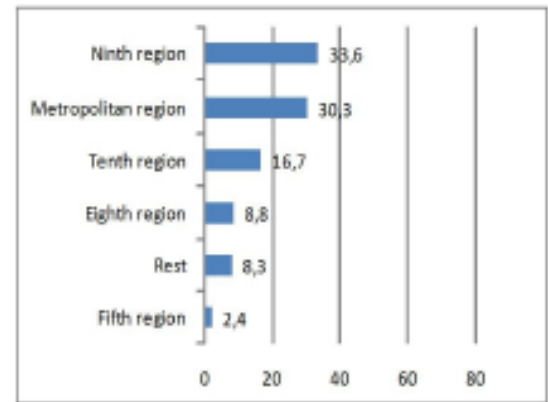

Figure 1. Mapuche distribution in Chile regions (CENSO, 2017)

The research question arised in this work is; How is it possible to preserve the vitality of Mapuche language given a model of linguistic displacement as a language dominated by Spanish in a dominant position?

This work suggests a platform for knowledge management that acts as teaching and learning of Mapuzugun as a pedagogical resource in the educational actors for Mapuche as the ethnic recessive language.

The work structure is done with Mapuche native backgrounds, therefore, here we explained the fundamentals of the alphabets, learning styles, the importance of technologies and information in classrooms, mapuzugun syntax, Kimun platform development, results, conclusions and references. 


\section{ALPHABETS}

\subsection{Ranguleo Alphabet}

The Raguileo alphabet was created in 1982 by Anselmo Raguileo, an intellectual who, according to data provided by Ruby Raguileo (Wittig, 2015), (Scott et al., 2013), participated in Mapuche movements emphasizing the political importance of maintenance the language for the existence of the Mapuche people, he was professor of Mapuche language at the Pedagogical Institute of the University of Chile in the 50's and in 1973 he graduated as Engineer in Chemistry Execution. In the 1980s, back in Temuco, he did fieldwork in mapuche communities in different regions for a CAPIDE linguistic project, and to test the reliability of the alphabet between 1982 and 1990 he did different Mapuche language courses at CAPIDE, Ad Mapu and the Newen Mapuche Society. We agree with Wittig (Wittig, 2015) that "the Raguileo Alphabet is based on a position of differentiation and autonomy of the Mapuche language in relation to Spanish; the language of the dominant society" in what differs fundamentally from the Unified Alphabet. This alphabet is composed of the following graphemes: a, c, z, e, f, q, i, k, l, b, j, m, n, h, , g, o, x, u, v, w, y.

\subsection{Unified Mapuche Alphabet}

In the Unified Mapuche Alphabet presentation, Mario Bernales (Chilean Society of Linguistics, SOCHIL in spanish, 1988) (Sochil, 1988) points out - perhaps anticipating future discussions about this subject - that: The deliberate development of a writing system for the language of an unlettered society has place within a complex of historical and sociocultural factors and exceeds the purely technical problems of representing a phonology by an alphabet. The Unified Mapuche Alphabet was thought from a schooling that provides literacy in the Spanish language, and in a historical moment in which Mapuche movements did not manifest the current political protesting force. The proposal reached a high level of diffusion. As Wittig points out (Wittig, 2015), The fact that this alphabet is supported by the academic community promoted its use in teaching Mapudungun. It is a Roman alphabet with five additions (l, n, , t , ) and four digraphs (ch, ll, ng, tr), thus it is made of 28 graphemes (Salamanca et al., 2009), (CONADI, 2008): a, ch, d, e, f, G, i, k, l, ll, m, n, ñ, $\mathrm{ng}$, or p, r, s, t, t, tr, u, ü, w, y, sh.

\subsection{Azümchefe Alphabet}

This proposal (CONADI, Azümchefe, Study for the definition, 107) (CONADI, 2008) is born as an attempt to generate and legitimize only one alphabet for the Mapuche people - that responds to the aspiration of people dream, so as to transcribe the phonetics of the mother tongue and that can be used as a means of advancement to the utopia of Mapuche people" (CONADI, Azümchefe., Sole Graphite, 23). Based on the analysis of six previous alphabets (Antinao, Caulef, Painequeo, Huilcamn, Raguileo and Unified), it consists of 28 linguistic codes or letters (6 vowels and 22 consonants). Two of the consonants represent expressive sounds: one affective and one derogatory. Azmchefe means person who learns. This alphabet was created by CONADI and gathers features of the Rangileo and the Unified alphabet and consists of 28 letters: a, $\mathrm{z}, \mathrm{u}, \mathrm{m}$, ch, e, f, i, k, t, nh, tx, y, q, g, lh, n, r, s, ll, p, u, w, l, n, sh, t.

\section{LEARNING STYLES}

At school there is a consensus about the need to observe the diversity of students, and based on this, to develop technological tools appropriate to current educational contexts. This implies a challenge for the education system. In this sense, the main approaches are directed towards the individual preferences, which would enhance the cognitive capacities (Alvarez-Santullano et al., 2015) and the student performance. From this perspective, studies are positioned around the students learning styles (Bisol et al., 2015), the learning styles refer to the habitual mechanisms to perceive, interact and respond in a teaching and learning context. 
The learning process is facilitated when the professor teaches from the predominant style of the student, both visual and auditory.

The model called visual-auditory, it is named so because it takes into account two large systems to mentally represent the information. The visual representation system is used whenever we remember images. The system of auditory representation allows us to hear voices, sounds and music in our minds. Using visual and auditory activities influences student learning. When information is presented, or when you have to do an exercise, in the preferred representation system, it is easier to understand and learn (Lévano, Albornoz and Venegas, 2017), (Turcsanyi-Szab, 2012).

\section{INFORMATION TECHNOLOGIES IN CLASSROOMS}

Between the advantages of information technologies in classrooms we find (Lévano, Albornoz and Venegas, 2017), (Lévano and Fernandez, 2015):

- From the pedagogical point of view: It allows a greater differentiation of students and create personalized activities according to their learning styles, teaching becomes more interactive and students become more involved in the teaching process.

- It generates autonomous learning: The fact that teaching becomes interactive and therefore the student becomes more involved in the teaching process contributes to the students assuming a greater responsibility in their own learning.

- Motivation: Today we have a generation called "digital natives" in which the use of technology is a fundamental part of how they relate to the environment, which is why the use of interactive content and multimedia materials causes greater attention and motivation of the student to learn.

- More teacher support: The use of IT provides the teacher with a greater number of tools, content and didactic resources that help him to develop a more interactive teaching environment.

\section{TECHNOLOGY AND LANGUAGE LEARNING}

ICTs have attained a significant role as support for learning, the acquisition of new knowledge and the development of new abilities. Nowadays, the use of technology applied to education can be seen through the use of different resources: Webquest, augmented reality, educational gamification, etc. (Gutierrez-Castillo, Puig, and Romero, 2018) Within the games-based learning (GBL), the most recurrent areas are mathematics, health, science and languages. The latter, recently explored in platform games, with computers being its main instrument (Hung et al., 2018).

The setback that can arise is the access or knowledge about technologies, which translates into a barrier especially in rural sectors where digital gaps are greater. Therefore, ICT represent an opportunity to amend differences between educational systems taught in the countryside and the city. The previous idea ought to consider a context of participation and social inclusion (UNICEF, 2017).

Linking this fact to the teaching of Mapuzugun, there will not only be a cultural recovering but also incorporation of useful technologies for the digital connectivity of the new generations (UNICEF, 2017).

\section{MAPUZUGUN SYNTAX}

As is known, the syntax is the correct construction of grammatical sentences, without the notions of syntax you would not know how to combine and relate to each other the language primordial elements. In simple words, the syntax teaches the order and dependence of words in the sentences.

In there is also an order and dependence of the words that make up the sentences, the Mapuzugun syntax (SOCHIL, 1988; Salamanca et al., 2009) has the following structure.

- In Mapuzugun we find phrases without a verb, in this case the syntactic order of the sentence would be: first the adjective and then the noun (See table 2). 
Table 2. Mapuzugun Syntax Example without Verbs

\begin{tabular}{|c|c|c|}
\hline Adjective & Noun & Example \\
\hline Kuru & ufisha & black sheep \\
\hline Futra & kuw $\ddot{u}$ & big hand. \\
\hline Motrin & kawell & Big horse. \\
\hline
\end{tabular}

- In Mapuzugun we also find sentences having verb, in this case the sentence syntactic order would be: first the verb, second the adjective and finally the noun (See table 3).

Table 3. Example of Mapuzugun Syntax with Verbs

\begin{tabular}{|c|c|c|c|}
\hline Verb & Adjective & Noun & Example \\
\hline Nien & Epu motrin & Kawell & I have two big horses. \\
\hline Niey & Küla kad $\ddot{u}$ & Trewa & He has three grey dogs \\
\hline
\end{tabular}

- The above syntactic order allows to elaborate any type of sentence in Mapuzugun, but in addition to the use of the verb, adjective and noun can add the use of adverbs. In the case of adverbs, these do not occupy a definite position within the sentence, so they can go to the beginning of this, the end or between the other words (See table 4).

As we can appreciate the adverbs can be used anywhere in the sentence and allow to modify the sense of this and elaborate even more complicated ideas. Following the Mapuzugun syntactic order and applying this language grammatical laws, we can make simple and complex sentences that allow us to communicate in written form through clear and precise ideas.

Table 4. Mapuzugun Syntax Example with Verb, Adjective and Noun

\begin{tabular}{|c|c|}
\hline parts of the sentence & sentence \\
\hline Verb & Muley \\
\hline Adverb & Kiñe \\
\hline Plural & Kechan \\
\hline Adjective & Kur ̈̈ \\
\hline Noun & ufisha \\
\hline Adverb & Lelfün \\
\hline Adverb & Mew \\
\hline
\end{tabular}

\section{KIMUN PLATFORM DEVELOPMENT}

\subsection{Platform}

Use cases (see figure 2) Kimun platform is designed with eight functionalities as described below:

- Registration: in this use case the functionality is centered on the player's registration, which is entered into a database of players who are part of the class or group of learners.

- Games: in this use case the functionality allows to offer games such as the human body, puzzle, flora and fauna, sentences, exploring agent and tones.

- Levels: in this use case the functionality consists in as the player achieves reward, the system offers you new levels of adventure.

- Worldview: in this use case the functionality lies in showing the Mapuche world where multimedia is integrated, such as sound, image and texts.

- Evaluation: in this use case the functionality allows the trainer / teacher to evaluate the progress of Mapuzugun learning schemes.

- Reflections: in this use case has the functionality that the learner or student notes learned situations about contexts.

- Feedback: in this use case, the functionality is focused on leaving notes by the instructor / teacher for the mistakes that the learner makes.

- Scores: this use case has the functionality to give reward for each level of advance that the learner achieves, which in software is denominated as gamification 


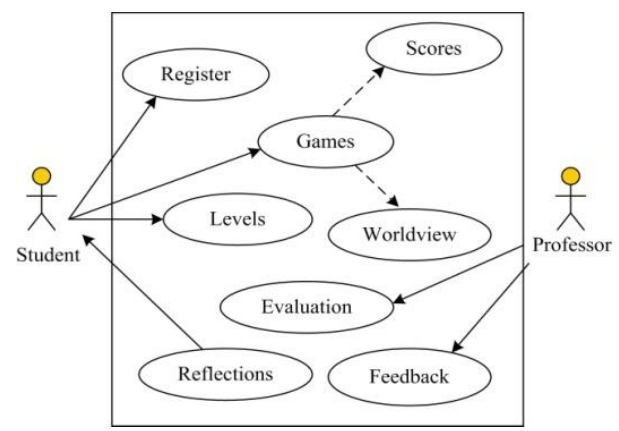

Figure 2. Kimun Platform

\subsection{Pedagogical Treatment Design for Learning}

The proposed instrument is an experiential learning centered on the student with focus on knowledge: being, doing, and knowing. An instrument to safeguard the cognitive process balance is based on the fact that it must maintain the triple concordance in methodology, learning outcomes and knowledge assessments.

The instrument systematization to be addressed by the teacher is: Identification, Learning sense, Closed examples, Activities, Assesments schemes and Support sources.

\section{PLATFORM RESULTS}

Among the platform results responding to the process of cognitive development.

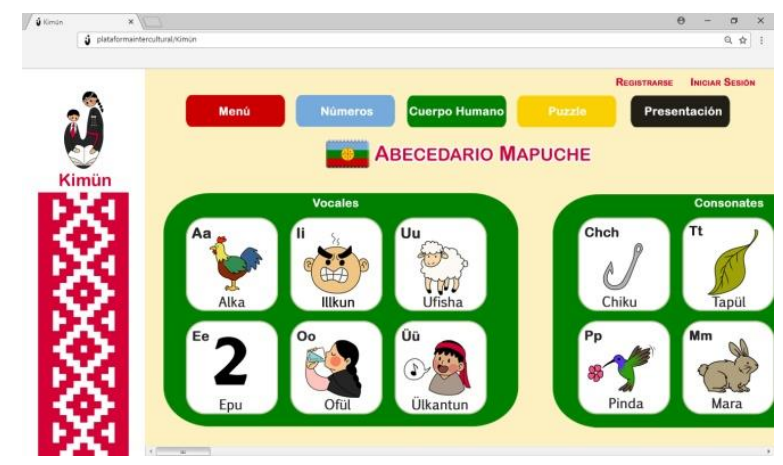

Figure 3. Mapuche Alphabet Interface

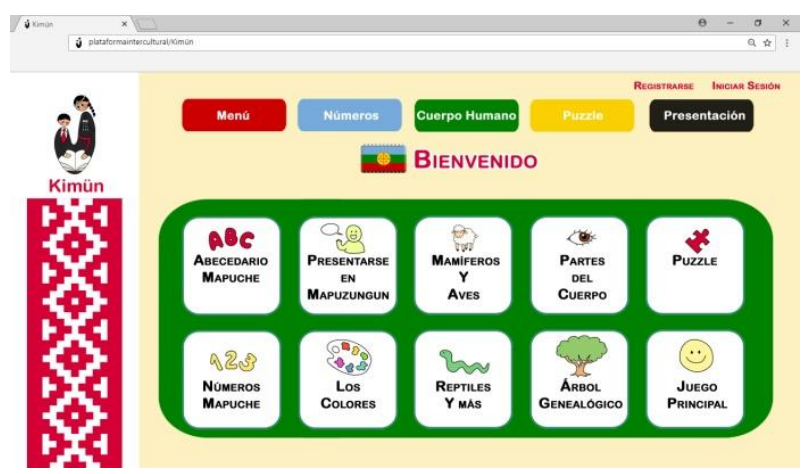

Figure 4. Interface of Games that develop the Cognitive Process 


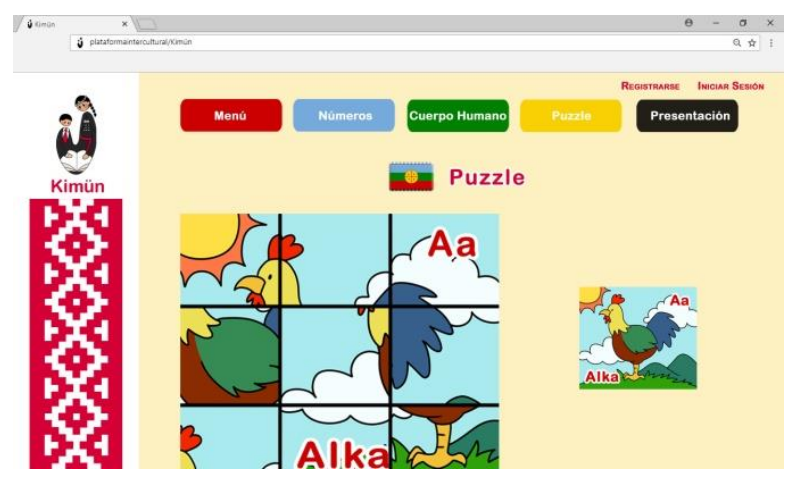

Figure 5. Working Puzzle

Note:

Step 6: Contextualize the solution to another problem.

Step 5: Discuss and criticize the solution.

Step 4: Break down the parts of the result.

Step 3: Modeling application to the problem.

Step 2: Phenomena interpretation to the model.

Step 1: Modeling and Knowledge.

Table 5. Cognitive Process Framework for Mapuzugun

\begin{tabular}{|l|c|l|}
\hline Methodology & Bloom taxonomy & Mapuzugun \\
\hline Step 6 & Creation & Worldview association. \\
\hline Step 5 & Assesment & Reflect. \\
\hline Step 4 & Analysis & Association and sense in paragraphs. \\
\hline Step 3 & Application & Alphabets: sentences \\
\hline Step 2 & Understanding & Interpret the alphabet meaning. \\
\hline Step 1 & Knowledge & Alphabet. \\
\hline
\end{tabular}

In Figures 3, 4 and 5 it can be observed that each component designs learning objects (OVAs) as a student learning resource.

\section{CONCLUSIONS}

Facing the phenomenon of the socio-cultural linguistic displacement model can be incubated from the original indigenous peoples without causing cultural disturbances in an invasive way. In spite of the predominance of the Spanish against Mapuzugun language with the help of the communication and information technologies support we can diminish the disappearance of Mapuche language.

Nowadays, in a knowledge society, users are the generators of our own knowledge and we can give the paths to the native speakers to be transported by this Kimun platform, because it is possible to generate Mapuzugun transculturization and conservation. The separability gap between cultures because of conquests can lessen the otherness between different worldviews with technologies help such as web 3.0 (Bisol et al., 2015), (Dabbagh and Reo, 2011).

\section{ACKNOWLEDGEMENT}

The present work is grateful to the Informatics Engineering Department for the collaboration in the laboratories for the development of the work. 


\section{REFERENCES}

Alvarez-Santullano P., Forno Sparosvich A. and Risco del Valle E. Grapheme alphabet proposals for mapuche language: from phonemes to political and identity representations. ALPHA 40 (2015), 113-130.

Bisol et al. 2015. Teacher education for inclusion: Can a virtual learning object help?. Computers \& Education Vol. 85, pp. 203-210.

CENSO (2017). Resultados del Censo 2017. Retrieved from: https://resultados.censo2017.cl/

Rodolfo Lenz. Estudios Araucanos: Materiales para el Estudio de la Lengua, la literatura y las costumbres de los indios Mapuche o Araucano. Anales de la Universidad de Chile 1895-1897.

Centro de Estudios Públicos (CEP). 2007. Estudio Opinión Pública: los mapuches urbanos y rurales hoy. Documento de Trabajo N 367, Santiago: CEP.

CONADI. Az'umchefe. Grafemario del idioma mapuche. Estudio para la definición de un grafemario para la lengua mapuche. Temuco: Departamento de Cultura y Educacion, CONADI, 2008.

Dabbagh, N. and Reo, R. (2011). Back to the future: Tracing the roots and learning affordances of social software. In M.J.W. Lee, and C. McLoughlin (Eds.), Web 2.0-based e-learning: Applying social informatics for tertiary teaching. Hershey, PA: IGI Global.

Gundermann, Hans. 2005. "Estudio del contexto sociolinguistico de comunidades aymaras, atacameñas y mapuche de Chile". En Jorge Ivn Vergara y Hans Gundermann (ed): Descripción del contexto sociolinguístico en comunidades indigenas de Chile, Santiago: Programa EIB MINEDUC Programa Origenes, pp.13-97.

Gundermann H., Canihuan J., Claveri A. and Faundez C. Revista de Lingüistica Teórica y Aplicada Concepción (Chile), 47 (1), I Sem. 2009, pp. 37-60.

Gutierrez-Castillo, J., Puig, G., \& Romero, T. (2018). Innovación y Tecnología en Educación Infantil. Retrieved from: http://dx.doi.org/10.12795/9788447221097

Hung, H., Yang, J., Hwang, G., Chu, H., \& Wang, C. (2018). A scoping review of research on digital game-based language learning. Computers \& Education, 126, 89-104. doi:10.1016/j.compedu.2018.07.001

Levano, M. and Fernandez, C. (2015): A model for a physical and virtual environment for extreme feedback in the development of the metacognition supported by TICS: The computer engineer career as case of study. Lecture Notes in Electrical Engineering, 330, 1345-1352.

Levano M, Albornoz A, Venegas G. (2017). Framework based on stem for the Development of programming competence: Case study of modeling of problems in Engineers training. Budapest, Hungary: IADIS Press.

Sadowsky, Scott et al. Illustrations of the IPA. Mapudungun, Journal of the International Phonetic Association (2013): 87-96.

SOCHIL. Sociedad Chilena de Linguistica. Alfabeto Mapuche Unificado. Temuco: Universidad Catolica de Temuco, 1988.

Salamanca, Gaston et al. Mapuche hablado en Melipeuco: Fonemas segmentales, fonotaxis y comparación con otras variedades, LOGO Revista de Linguistica, Filosofia y Literatura (2009): 74-95.

Turcsanyi-Szab Mrta. 2012. Aiming at Sustainable Innovation in Teacher Education from Theory to Practice. Informatics in Education, 2012, Vol. 11, No. 1, pp. 115-130.

UNICEF (2017). El Estado Mundial de la Infancia 2017: Niños en un mundo digital. Retrieved from: https://www.unicef.org/paraguay/spanish/UN0150440.pdf

Wittig, Fernando. La escritura en mapudungun: alfabetos en uso y nuevos escenarios. CISAI. Centro interdipartimentale di studi sull'america indigena. Universitad Degli Studi di Siena (2006). Rescatado el 2 de febrero de 2015. Disponible en: http://www.unisi.it/cisai/arealingtesti.htm 